\title{
In Vitro Inhibition of Acetylcholinesterase, Alphaglucosidase, and Xanthine Oxidase by Bacteria Extracts from Coral Reef in Hainan, South China Sea
}

\author{
Lin Tan ${ }^{1}(\mathbb{1})$, Suxia Guo ${ }^{1}$, Funing Ma ${ }^{1}(\mathbb{D})$, Chen Chang ${ }^{2}$ and Isabel Gómez-Betancur ${ }^{1,2,3, *(1)}$ \\ 1 Haikou Experimental Station, Chinese Academy of Tropical Agricultural Sciences (CATAS)-Hainan Key \\ Laboratory of Banana Genetic Improvement, Haikou 570102, Hainan, China; tanlin7402@126.com (L.T.); \\ guosuxia@gmail.com (S.G.); funingma@163.com (F.M.) \\ 2 Key Laboratory of Tropical Marine Bio-resources and Ecology, South China Sea Institute of Oceanology, \\ Chinese Academy of Sciences, Guangzhou 510301, Guangdong, China; chen.chang@scsio.ac.cn \\ 3 Programa de Ofidismo/Escorpionismo, Facultad de Ciencias Farmacéuticas y Alimentarias, \\ Universidad de Antioquia, 1226 Medellín, Colombia \\ * Correspondence: isabel.gomez@inemjose.edu.co; Tel.: +86-181-897-88-716
}

Received: 18 February 2018; Accepted: 27 March 2018; Published: 5 April 2018

\begin{abstract}
Acetylcholinesterase is one of the most important enzymes in living organisms, which is responsible for the synapse cholinergic and other nervous processes. However, its inhibiting effects have proven to have pharmacological applications in the treatment of different diseases, as well as in the control of insect pests; thus, the search for inhibitors is a matter of interest for biomedical and agrochemical fields. Alzheimer's is a progressive neurodegenerative disease, which can be seen as a wide degeneration of synapses, as well as neurons, in the cerebral cortex, hippocampus, and subcortical structures. Acetylcholinesterase inhibition is an important target for the management of Alzheimer's. Additionally, diabetes mellitus is a chronic disease with clinical manifestation of hyperglycemia, due to the ineffective production of insulin that controls the level of blood glucose. Alphaglucosidaseinhibitors could retard the uptake of dietary carbohydrates and have shown significant therapeutic effects in clinical application. Fifty-five ethyl acetate extracts from nine bacterial families from Hainan (China) were evaluated to observe their acetylcholinesterase, alphaglucosidase, and xanthine oxidase inhibitory activity. Moreover, a screening of inhibitory activity against the pathogens fungi Fusarium oxysporum and Colletotrichum gloeosporioides was performed. The best acetylcholinesterase and alphaglucosidase inhibitory activity was shown by Vibrio neocaledonicus $(98.95 \%)$. This is the first report of inhibition of both enzymes by ethyl acetate extract from this strain.
\end{abstract}

Keywords: Vibrionaceae; Vibrio neocaledonicus; acetylcholinesterase; alphaglucosidase; Colletotrichum gloeosporioides; Fusarium oxysporum

\section{Introduction}

Acetylcholinesterase (AChE) is an enzyme from the hydrolases group that is present in the majority of living beings, mainly in vertebrates including humans, but also on invertebrates such as insects. It is located in the nervous system and muscles, and is responsible for the regulation of the concentration of acetylcholine $(\mathrm{ACh})$, a neurotransmitter involved in the Synapse cholinergic nervous system, allowing the nerve signal transmission in the central and peripheral nervous system [1]. Acetylcholinesterase inhibitors (AChEIs) comprise a large number of compounds with varied structures that have the ability to interact with the enzyme to inhibit it to a greater or lesser extent [2].

Bioprospecting studies in search for AChEIs have been encouraged due to the many different applications that this type of compounds has, either in the field of medicine or agroindustry. These 
inhibitors have been sought mainly in plants [3,4]. In addition, in the marine environment, compounds with inhibitory activity of $\mathrm{AChE}$ have been found. Among the compounds isolated from marine sources, there are diterpenes isolated from the octocoral Lobophytum cembrane type sp. [5], steroidal alkaloids isolated from the sponge Corticium sp. [6], phlorotannins of the algae Ecklonia stolonifera [7], and piridoacrinic alkaloids from Petrosia sp. sponge [8].

AChEIs are the most popular drugs applied in the treatment of diseases such as Alzheimer's disease [9,10], Parkinson's disease, senile dementia, and ataxia, among others [11]. Some of the most commonly used AChE inhibitors are galantamine, rivastigmine, and donepezil; however, it is known that these drugs have limitations for clinical use due to their unfavorable side effects [12].

On the other hand, Diabetes Mellitus Type II is a metabolic disorder characterized by permanent hyperglycemia, which is caused by defects in insulin secretion. Chronic hyperglycemia is associated with damage, dysfunction, and failure of various organs [13]. The inhibition of the enzymes necessary for the digestion of polysaccharides (carbohydrases) is one of the alternatives to antidiabetic drugs [14]. Studies focused on the seek of medicinal plants that inhibit carbohydrases have been reported [15-17], finding valuable information, particularly in plants with the presence of flavonoids, polyphenols, and sugar derivatives [18].

Nowadays, almost half of the drugs that exist are inhibitors of enzymes related to various diseases [19]. Among the bioassays with better enzymes, the inhibition of AchE [20] is one of the best known, given its potential implementation in the treatment of different diseases. Marine organisms are recognized as a source of compounds with biological activity equal to or greater than terrestrial organisms [21], but there are few examples of systematic searches of compounds with activity AChEI and AGI among marine organisms, and the fact that there is still great interest in finding novel and better AChEIs and AGIs prompted us to screen 55 ethyl acetate extracts belonging to 9 different bacterial families: Vibrionaceae, Bacillaceae, Microbacteriaceae, Aerococcaceae, Brevibacteriaceae, Staphylococcaceae, Pseudoalteromonadaceae, Enterobacteriaceae, and Shewanellaceae due to their AChE and AG inhibitory activity. The majority of the strains evaluated in the present study belong to the Vibrionaceae (45.4\%) and Bacillaceae (29.1\%) families.

Vibrionaceae is a large family of marine Gram-negative Gammaproteobacteria, which includes organisms of different environments, such as symbionts, bioactives, and pathogenic organisms [22-24]. Another interesting family is the Bacillaceae, widely distributed in natural environments such as air, soil, and sediments [25-30].

Considering the importance and great diversity of marine microorganisms, we started to analyze the prevalence of AChEIs and AGIs in marine bacteria isolated from different samples of reef coral, using a high throughput microplate-based assay. Furthermore, we tried 12 marine bacteria strains on XO inhibitory activity. Moreover, in order to contribute to the knowledge of the bacteria chosen for the activities described above, a screening of antagonistic bacteria to evaluate activity against two pathogens fungi that seriously affect large and important crops such as banana and mango in tropical and subtropical areas was done. In this research report, we outline an interesting finding about the inhibition of the activity of AChE and AG enzymes by ethyl acetate bacterial extracts coral reef in the South China Sea.

\section{Materials and Methods}

\subsection{Reagents}

Acetylcholinesterase from Electrophorus electricus, alphaglucosidase from Saccharomyces cerevisiae, and xanthine oxidase from bovine milk were obtained from Sigma Aldrich. The other reagents used in the bioassays were purchased either from Sigma Aldrich or Solarbio. Reagents to perform the extraction were purchased from XL Xilong Scientific Chemical. Silica gel plates (Silica gel $60 \mathrm{~F}_{254}$ $0.2 \mathrm{~mm}$ layer thickness) were purchased from Merck (KGaA, Darmstadt, Germany). Multiskan GO 
(Thermo Scientific, Shanghai, China) spectrometer was used for all measurements of AChE, AG, and XO inhibitory activity.

\subsection{Marine Bacterial Strains}

55 bacterial strains were obtained using traditional methods of farming. These strains were associated with coral reef from South China Sea (China). The bacteria were identified and categorized using both conventional molecular methods (16S rRNA gene sequencing) and its morphological characteristics. The bacterial isolates were preserved in marine medium Difco 2216 semi-solid at $4{ }^{\circ} \mathrm{C}$ until they were used for cultivation. Each of the bacteria was cultivated $(150 \mathrm{~mL} \times 2)$ in growing $2216 \mathrm{E}$ Liquid Medium (Qingdao Hope Bio-Technology Co. Ltd., Qingdao, China) for $76 \mathrm{~h}$ at $25^{\circ} \mathrm{C}$ and with a stirring of $100 \mathrm{rpm}$. To prepare the 2216E culture medium $(37.4 \mathrm{~g} / 1000 \mathrm{~mL}$ of distilled water), it was subjected to autoclaved material. The water used was distilled through an AXL Water water purifier. All means and instruments used in microbiology were sterilized with steam in a Zealway GI54DW autoclave of $32 \mathrm{~L}$ to $20 \mathrm{psi}$ and $121^{\circ} \mathrm{C}$ for $20 \mathrm{~min}$. The innocuous ones were prepared in cabin flow laminar ZJ (SW-CJ-1D). Incubation of agar plates was conducted in a ZHWY-2112B Incubator shaker at $29^{\circ} \mathrm{C}$.

\subsection{Extraction Process}

The biomass was separated by centrifugation at $8000 \mathrm{rpm}, 10 \mathrm{~min}$, at $29^{\circ} \mathrm{C}$ in Thermo Scientific Heraeus Multifuge X3R centrifuge. Subsequently, the supernatant was filtered and the strain was subjected to extraction. Extracts were evaluated in the trial of AChEI, AGI, and XOI activity.

\subsection{Acetylcholinesterase Inhibition Assay}

AChE inhibition was determined according to the method of Ellman [31], with acetylthiocholine iodide (ATCI) as substrate. In short, to a 96-well microplate, $20 \mu \mathrm{L}$ of $10 \mathrm{mmol} / \mathrm{L}$ ATCI, $10 \mu \mathrm{L}$ of different concentrations of sample, $10 \mu \mathrm{L}$ of $0.22 \mathrm{U}$ AChE, $40 \mu \mathrm{L}$ of $0.02 \mathrm{~mol} / \mathrm{LPBS}$ (pH 7.4) after incubation at $37{ }^{\circ} \mathrm{C}$ for $30 \mathrm{~min}$, and $20 \mu \mathrm{L} 4 \mathrm{SDS}$ were added to stop the reaction. Then, $100 \mu \mathrm{L}$ of $2.5 \mathrm{mmol} / \mathrm{mL} \mathrm{5,5-dithiobis-2-nitrobenzoate} \mathrm{(DTNB)} \mathrm{was} \mathrm{added} \mathrm{to} \mathrm{produce} \mathrm{the} \mathrm{color.} \mathrm{All} \mathrm{the}$ above-mentioned concentrations are final concentrations in the assay.

The OD was measured at $405 \mathrm{~nm}$ in a spectrometer Thermo Scientific Multiskan GO. All measurements were performed in triplicate with Huperzine-A as positive control. Control contained all components except the tested sample. The chemical principle of the reaction is represented in Figure 1.

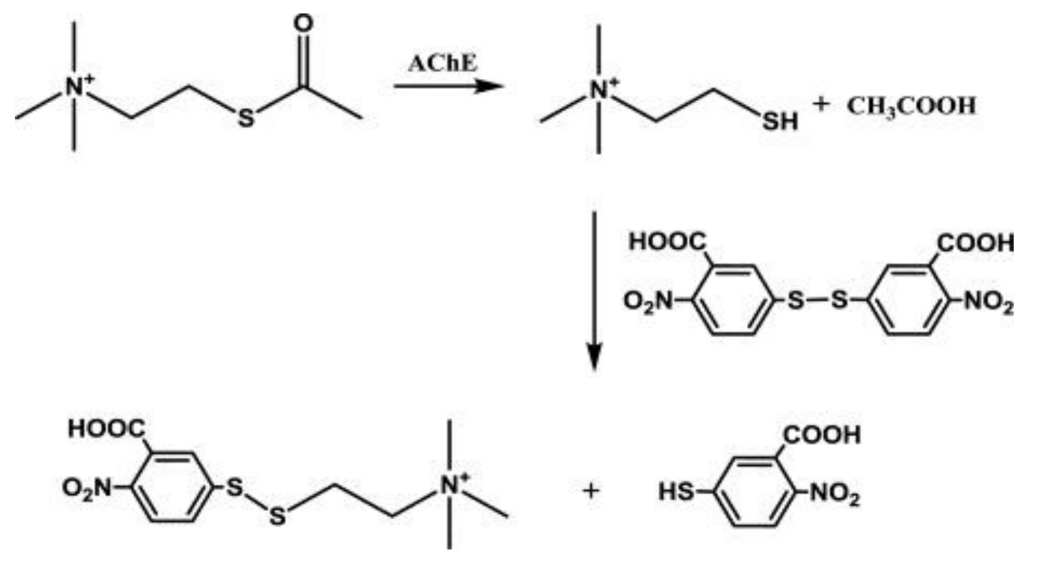

Figure 1. Chemical mechanism of Ellman's method. The enzyme hydrolyzes the substrate ATCI to thiocholine and acetic acid. Thiocholine is allowed to react with DTNB, and this reaction resulted in the development of a yellow color [32]. 
The inhibitory rate was calculated as the formula:

$$
\% \mathrm{I}=(1-(\mathrm{ODs}-\mathrm{ODsb}) / \mathrm{ODn}-\mathrm{ODnb}) \times 100 \%,
$$

in which ODs is the absorbance value of the sample system, ODsb is the absorbance of ODs in which no AchE was added, ODn is the absorbance value of the sample system in which sample is substituted by PBS, and ODnb is the absorbance value of ODn in which no AChE was added.

\subsection{Alphaglucosidase Inhibition Assay}

The alphaglucosidase inhibition activity was evaluated by measuring the release of $p$-nitrophenol from $p$-nitrophenyl- $\alpha$-D-glucopyranoside ( $p$ NPG) following the method proposed by Pistia-Brueggemann, with slight modifications [33]. The assay contained $80 \mu \mathrm{L}$ of phosphate buffer (PBS 0.5 M, pH 6.8), $10 \mu \mathrm{L}$ of $3.0 \mathrm{mmol} / \mathrm{L}$ L-glutathione (reduced-Solarbio Life Sciences, Beijing, China) solution to protect the enzyme, $20 \mu \mathrm{L}$ of $\alpha$-glucosidase $(0.57 \mathrm{U} / \mathrm{mL})$, and $40 \mu \mathrm{L}$ of pNPG $(10 \mathrm{mmol} / \mathrm{L})$. All the above-mentioned concentrations are final concentrations in the assay. Control (C-) contains all the reagents, but sample is substituted by PBS. All measurements were carried out in triplicate with acarbose as positive control. The absorbance was read after incubation for $30 \mathrm{~min}$ at $37^{\circ} \mathrm{C}$ in a spectrometer Thermo Scientific Multiskan GO reader at $405 \mathrm{~nm}$.

\subsection{Xanthine Oxidase Inhibition Assay}

Xanthine oxidase $(\mathrm{XO})$ is an important enzyme that catalyzes the oxidation of purines, xanthine, and hypoxanthine, producing uric acid and hydrogen peroxide (Figure 2).<smiles>[H][Y10]([H])([AlH])n1cnc2c(=O)n([TlH])c(=O)n([AlH])c21</smiles>

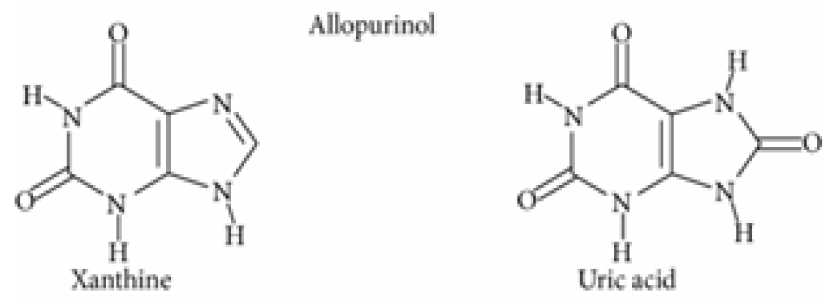

Figure 2. Inhibition of xanthine oxidase by allopurinol to prevent conversion of hypoxanthine to xanthine and/or uric acid [34].

The bioassay was based on the developed method of Valentao [35] and modified for application in microplates by Lopez [36]. All test samples were dissolved in a $50 \mathrm{mmol} / \mathrm{L}$ phosphate buffer to simulate the environment in which the reaction occurs in the body. The sample was mixed with $1.5 \mathrm{mmol} / \mathrm{L}$ xanthine solution and was maintained at room temperature. Three concentrations of sample solution were evaluated $(125.0 \mu \mathrm{g} / \mathrm{mL}, 62.5 \mu \mathrm{g} / \mathrm{mL}$, and $31.25 \mu \mathrm{g} / \mathrm{mL})$. Finally, $0.5 \mathrm{U} / \mathrm{mL}$ of enzyme XO solution was added, and the absorbance was recorded at $295 \mathrm{~nm}$. Moreover, allopurinol $1.2 \mathrm{mmol} / \mathrm{L}$ 
was used as a positive control. All the above-mentioned concentrations are final concentrations in the assay.

\subsection{Qualitative Chemical Analysis}

For the bacterial extracts that showed statistically significant results compared to the control in the acetylcholinesterase inhibition assay, a qualitative analysis was done in order to test the presence of groups of secondary metabolites using Thin Layer Chromatography (TLC). The solvent systems were: hexane-acetone 7:3 (strains with codes 1, 2 and 18), hexane-dichloromethane 6:4 (strains with codes $3,4,5,6,7,15,19,23,24,28,46$, and 49), and hexane-ethyl acetate 1:1 (strains with codes 18, 20, 26, 27 and 53); the plates were also observed in short and long wave in UV lamp, and the development was performed on aluminum plates coated with silica gel $60 \mathrm{~F}_{254}$. The following spray reagents were used: anisaldehyde-sulphuric acid (to look for presence of sterols, phenolic compounds, and terpenes) and Draggerdorf's reagent (to look for presence of alkaloids) [37].

\subsection{Screening of Antagonistic Bacteria}

Strain: Fusarium oxysporum f. sp. cubense race 4 (Foc4), kept in our lab. The Colletotrichum gloeosporioides $(\mathrm{Cg})$ was donated by the rubber tree disease resistance research group of Hainan University.

Media: The marine bacteria strains isolated from South China sea were grown using LB media (tryptone $10.0 \mathrm{~g} / \mathrm{L}$, Yeast extract $5.0 \mathrm{~g} / \mathrm{L}, \mathrm{NaCl} 10.0 \mathrm{~g} / \mathrm{L}$ ), while PDA (potato extract powder $6.0 \mathrm{~g} / \mathrm{L}$, dextrose $20.0 \mathrm{~g} / \mathrm{L}$, agar powder $25.0 \mathrm{~g} / \mathrm{L}$ ) was used to grow the two fungi and do bioassay of antagonistic activity against plant pathogen fungi.

\subsection{Activity: Screening of Antagonistic Bacteria}

Plate confrontation method was used to screen the antagonistic bacteria as described by Feng [38]. PDA plates were inoculated with Foc4 or Cg, respectively, in the middle of the plates. Then, the bacterial strains were incubated $2 \mathrm{~cm}$ away from the pathogen using sterile toothpicks. Plates were incubated at $30^{\circ} \mathrm{C}$ for 3 to 5 days. We determined the antagonism effect according to the zone of inhibition that was measured according to the method.

\section{Results}

The complete list of the strains assessed with their respective codes and families is shown in Table 1.

\subsection{Acetylcholinesterase and Alphaglucosidase Inhibition Assay}

55 extracts of marine bacteria were evaluated; 23 of them (41.1\%) showed strong to moderate AChE inhibitory activity, and only 2 strains (3.6\%) showed moderate AG inhibitory activity (Table 2). The inhibition activities of the ethyl acetate extracts evaluated on AChE and AG are shown in Table 2.

\subsection{Xanthine Oxidase Inhibition Assay}

In the presence of $15 \mu \mathrm{M}$ xanthine, ethyl acetate extract of the nine strains inhibited xanthine oxidase activity in a dose-dependent manner from $125 \mu \mathrm{g} / \mathrm{mL}$ and $62.5 \mu \mathrm{g} / \mathrm{mL}$ to $31.25 \mu \mathrm{g} / \mathrm{mL}$ (Table 3). The maximum of inhibition (25-31\%) was obtained by V. neocaledonicus extract (code 1, 14, 25 , and 38). 
Table 1. Marine bacteria evaluated on the enzymes acetylcholinesterase, alphaglucosidase, and on two pathogenic fungi.

\begin{tabular}{|c|c|c|}
\hline Strains Code & Family & Species \\
\hline 13 & Aerococcaceae & Aerococcus urinaeequi IFO 12173 \\
\hline 4 & Bacillaceae & Bacillus thuringiensis strain 61436 \\
\hline 8 & Bacillaceae & Bacillus amyloliquefaciens strain PD9 \\
\hline 12 & Bacillaceae & Bacillus subtilis \\
\hline 16 & Bacillaceae & Bacillus aerophilus \\
\hline 18 & Bacillaceae & Bacillus amyloliquefaciens \\
\hline 19 & Bacillaceae & Bacillus pumilus \\
\hline 20 & Bacillaceae & Bacillus velezensis strain Lzh-a42 \\
\hline 21 & Bacillaceae & Bacillus sp. \\
\hline 27 & Bacillaceae & Bacillus altitudinis \\
\hline 31 & Bacillaceae & Bacillus anthracis ATCC 14578 \\
\hline 33 & Bacillaceae & Bacillus aerophilus \\
\hline 36 & Bacillaceae & Bacillus thuringiensis strain 61436 \\
\hline 47 & Bacillaceae & Bacillus sp. strain M4 \\
\hline 50 & Bacillaceae & Bacillus subtilis \\
\hline 52 & Bacillaceae & Bacillus aerophilus \\
\hline 55 & Bacillaceae & Bacillus anthracis ATCC 14578 \\
\hline 37 & Brevibacteriaceae & Brevibacterium casei NCDO 2048 \\
\hline 49 & Enterobacteriaceae & Serratia marcescens strain UMH2 \\
\hline 11 & Micrococcaceae & Micrococcus sp. HW4 \\
\hline 10 & Pseudoalteromonadaceae & Pseudoalteromonas shioyasakiensis SE3(T) \\
\hline 46 & Shewanellaceae & Shewanella haliotis \\
\hline 53 & Shewanellaceae & Shewanella haliotis \\
\hline 26 & Shewanellaceae & Shewanella haliotis \\
\hline 2 & Staphylococcaceae & Staphylococcus kloosii ATCC 43959(T) \\
\hline 9 & Staphylococcaceae & Staphylococcus saprophyticus subsp. bovis GTC 843(T) \\
\hline 34 & Staphylococcaceae & Staphylococcus cohnii subsp. urealyticus ATCC(49330) \\
\hline 35 & Staphylococcaceae & Staphylococcus haemolyticus ATCC 29970 \\
\hline 39 & Staphylococcaceae & Staphylococcus cohnii subsp. cohnii ATCC 29974 \\
\hline 51 & Staphylococcaceae & Staphylococcus cohnii subsp. urealyticus ATCC 49330 \\
\hline 1 & Vibrionaceae & Vibrio neocaledonicus \\
\hline 3 & Vibrionaceae & Vibrio neocaledonicus \\
\hline 5 & Vibrionaceae & Vibrio neocaledonicus \\
\hline 6 & Vibrionaceae & Vibrio furnissii \\
\hline 7 & Vibrionaceae & Vibrio alginolyticus \\
\hline 14 & Vibrionaceae & Vibrio neocaledonicus \\
\hline 15 & Vibrionaceae & Vibrio diabolicus \\
\hline 17 & Vibrionaceae & Vibrio furnissii \\
\hline 22 & Vibrionaceae & Vibrio neocaledonicus NC470 \\
\hline 23 & Vibrionaceae & Vibrio antiquaries \\
\hline 24 & Vibrionaceae & Vibrio alginolyticus strain 27 \\
\hline 25 & Vibrionaceae & Vibrio neocaledonicus NC470 \\
\hline 28 & Vibrionaceae & Vibrio furnissii \\
\hline 29 & Vibrionaceae & Vibrio neocaledonicus \\
\hline 30 & Vibrionaceae & Vibrio antiquaries \\
\hline 32 & Vibrionaceae & Vibrio alginolyticus strain 27 \\
\hline 38 & Vibrionaceae & Vibrio neocaledonicus \\
\hline 40 & Vibrionaceae & Vibrio antiquaries \\
\hline 41 & Vibrionaceae & Vibrio neocaledonicus NC470 \\
\hline 42 & Vibrionaceae & Vibrio furnissii \\
\hline 43 & Vibrionaceae & Vibrio neocaledonicus \\
\hline 44 & Vibrionaceae & Vibrio sp. CF4-11 \\
\hline 45 & Vibrionaceae & Vibrio neocaledonicus \\
\hline 48 & Vibrionaceae & Vibrio neocaledonicus \\
\hline 54 & Vibrionaceae & Vibrio neocaledonicus \\
\hline
\end{tabular}


Table 2. Percentage inhibitory activities, on AChEof 23 ethyl acetate extracts of bacterial strains from coral reef collected on Hainan Island, South China Sea. (Final concentrations are shown).

\begin{tabular}{|c|c|c|c|c|c|}
\hline Code & Species & $\begin{array}{l}\% \text { AChEI } \\
50 \mu \mathrm{g} / \mathrm{mL}\end{array}$ & $\begin{array}{c}\% \text { AChEI } \\
25 \mu \mathrm{g} / \mathrm{mL}\end{array}$ & $\begin{array}{c}\% \text { AChEI } \\
12.5 \mu \mathrm{g} / \mathrm{mL}\end{array}$ & $\begin{array}{c}\% \text { AChEI } \\
6.25 \mu \mathrm{g} / \mathrm{mL}\end{array}$ \\
\hline $1 *$ & Vibrio neocaledonicus & $98.9^{* * *}$ & $69.9^{* *}$ & 21.78 & 11.0 \\
\hline 3 & Vibrio neocaledonicus & $93.0 * * *$ & $91.1^{* * *}$ & $50.2 *$ & 4.2 \\
\hline 38 & Vibrio neocaledonicus & $90.8^{* * *}$ & $88.8^{* * *}$ & 28.2 & 19.3 \\
\hline 10 & Pseudoalteromonas shioyasakiensis SE3(T) & $86.7^{* * *}$ & $84.1^{* * *}$ & 21.6 & 5.2 \\
\hline 28 & Vibrio furnissii & $89.3^{* * *}$ & $79.71^{* * *}$ & 0 & 0 \\
\hline 27 & Bacillus altitudinis & $83.3^{* * *}$ & $78.59 * * *$ & $79.88^{* * *}$ & 30.0 \\
\hline 49 & Serratia marcescens UMH2 & $76.4^{* *}$ & $52.1 *$ & 45.3 & 12.3 \\
\hline 20 & Bacillus velezensis Lzh-a42 & $71.0^{* *}$ & $62.5^{* *}$ & $58.2 *$ & 4.0 \\
\hline 46 & Shewanella haliotis & $66.7^{* *}$ & 24.49 & 10.20 & 0 \\
\hline $2 *$ & Staphylococcus kloosii ATCC43959(T) & $65.0^{* *}$ & 29.51 & 31.11 & 2.4 \\
\hline 15 & Vibrio diabolicus & $61.0 *$ & $63.38 * *$ & 45.07 & 40.1 \\
\hline 8 & Bacillus amyloliquefaciens PD29 & $59.6 *$ & $54.48 *$ & 45.07 & 15.5 \\
\hline 26 & Shewanella haliotis & $58.2 *$ & 49.95 & 45.91 & 12.3 \\
\hline 53 & Shewanella haliotis & $58.8 *$ & $50.47 *$ & 32.04 & 19.3 \\
\hline 19 & Bacillus pumilus & $57.0 *$ & $56.0 *$ & 48.32 & 30.3 \\
\hline 21 & Bacillus sp. & $56.28^{*}$ & 45.86 & 35.12 & 22.3 \\
\hline 18 & Bacillus amyloliquefaciens & $55.9 *$ & $52.45^{*}$ & 43.71 & 9.7 \\
\hline 23 & Vibrio antiquaries & $55.1 *$ & 39.49 & 19.46 & 0 \\
\hline 13 & Aerococcus urinaeequi IFO12173 & $54.6 *$ & 42.15 & 34.06 & 9.1 \\
\hline 5 & Vibrio neocaledonicus & $52.0 *$ & 34.54 & 12.25 & 0 \\
\hline 30 & Vibrio antiquaries & $50.0^{*}$ & 40.09 & 32.48 & 2.5 \\
\hline 6 & Vibrio furnissii & $50.2 *$ & 35.74 & 33.53 & 28.9 \\
\hline 24 & Vibrio alginolyticus & $50.9 *$ & 37.76 & 26.23 & 12.7 \\
\hline $\mathrm{C}+$ & Huperzine-A & & $98.9 \%$ & & \\
\hline
\end{tabular}

An analysis of one-way ANOVA non-parametric Kruskal Wallis with post-test Bonferroni was done. Significant differences were considered when the $p$ values were at least ${ }^{* * *} p \leq 0.001,{ }^{* *} p \leq 0.01,{ }^{*} p \leq 0.05$ compared with the negative control. $1^{*}$ (V. neocaledonicus) and $2^{*}$ (S. kloosii) showed moderate AGI inhibitory activity $(46.1 \%$ and $47.4 \%$ at $50 \mu \mathrm{g} / \mathrm{mL}$, respectively).

Table 3. Most active extracts in the Xanthine oxidase inhibition test. (Final concentrations are shown).

\begin{tabular}{|c|c|c|c|c|}
\hline Strain Code & Species & $\% X O I 125 \mu \mathrm{g} / \mathrm{mL}$ & $\% X O I \quad 62.5 \mu \mathrm{g} / \mathrm{mL}$ & $\% X O I \quad 31.25 \mu \mathrm{g} / \mathrm{mL}$ \\
\hline 25 & Vibrio neocaledonicus NC470 & 31.17 & 7.56 & 2.31 \\
\hline 3 & Vibrio neocaledonicus & 17.49 & 15.04 & 2.18 \\
\hline 1 & Vibrio neocaledonicus & 25.97 & 25.42 & 24.31 \\
\hline 14 & Vibrio neocaledonicus & 26.64 & 19.91 & 19.64 \\
\hline 38 & Vibrio neocaledonicus & 27.89 & 23.63 & 5.17 \\
\hline 10 & Pseudoalteromonas shioyasakiensis SE3(T) & 5.2 & 0 & 0 \\
\hline 2 & Staphylococcus kloosii ATCC43959(T) & 16.34 & 10.1 & 7.81 \\
\hline 24 & Vibrio alginolyticus & 20.96 & 8.67 & 3.63 \\
\hline 9 & Staphylococcus saprophyticus subsp. bovis & 16.17 & 10.37 & 0 \\
\hline 13 & Aerococcus urinaeequi IFO12173 & 23.91 & 17.55 & 0 \\
\hline 8 & Bacillus amyloliquefaciens PD29 & 0 & 0 & 0 \\
\hline 50 & Bacillus subtilis & 15.42 & 4.29 & 0 \\
\hline $\mathrm{C}+$ & Allopurinol & & $96.37 \%$ & \\
\hline
\end{tabular}

An analysis of one-way ANOVA non-parametric Kruskal Wallis with post-test Bonferroni was used. Significant differences were considered when the $\mathrm{p}$ values were at least $p \leq 0.001$ compared with the negative control.

\subsection{Qualitative Chemical Analysis}

The TLC plates were sprayed with $p$-anhisaldehyde, and different colors were observed that correspond mainly to compounds of the phenolic type, terpenes, and flavonoids. The anisaldehyde with sulfuric acid allows to visualize terpenoids in color from violet to red; flavonoids in yellow color can be observed and in brown, phenolic compounds [39]. Draggerdorf reagent was used to detect the presence of alkaloids, and orange color was observed in the strains with codes 6, 8, 20, 21, 24, and 28. All of them correspond to the genus Vibrio and Bacillus (Table 4). For detailed information, see the supplementary material (Figure S1: Qualitative chemical analysis). 
Table 4. Qualitative Chemical analysis of 23 ethyl acetate extracts of bacterial strains from coral reef collected from Hainan Island, South China Sea.

\begin{tabular}{|c|c|c|c|c|}
\hline Code & Species & Alkaloids & Terpenes & Polyphenols \\
\hline 1 & Vibrio neocaledonicus & - & + & + \\
\hline 3 & Vibrio neocaledonicus & - & + & + \\
\hline 38 & Vibrio neocaledonicus & - & + & + \\
\hline 10 & Pseudoalteromonas shioyasakiensis SE3(T) & - & - & + \\
\hline 28 & Vibrio furnissii & + & + & + \\
\hline 27 & Bacillus altitudinis & - & - & + \\
\hline 49 & Serratia marcescens UMH2 & - & - & + \\
\hline 20 & Bacillus velezensis Lzh-a42 & + & + & + \\
\hline 46 & Shewanella haliotis & - & + & + \\
\hline 2 & Staphylococcus kloosii ATCC43959(T) & - & + & + \\
\hline 15 & Vibrio diabolicus & - & + & + \\
\hline 8 & Bacillus amyloliquefaciens PD29 & + & + & + \\
\hline 26 & Shewanella haliotis & - & + & + \\
\hline 53 & Shewanella haliotis & - & - & + \\
\hline 19 & Bacillus pumilus & - & + & + \\
\hline 21 & Bacillus sp. & + & - & + \\
\hline 18 & Bacillus amyloliquefaciens & - & + & + \\
\hline 23 & Vibrio antiquaries & - & + & + \\
\hline 13 & Aerococcus urinaeequi IFO12173 & - & - & + \\
\hline 5 & Vibrio neocaledonicus & - & + & + \\
\hline 30 & Vibrio antiquaries & - & + & + \\
\hline 6 & Vibrio furnissii & + & - & + \\
\hline 24 & Vibrio alginolyticus & + & + & + \\
\hline
\end{tabular}

\subsection{Screening of Antagonistic Bacteria}

Plate confrontation assay were done with 55 bacteria strains. Results showed that 8 of them are active against Fusarium oxysporum $\mathrm{f}$. sp. cubense race 4 (Foc4), and 12 strains are active against Colletotrichum gloeosporioides (Cg) (Table 5). These antagonistic strains are mainly from Bacillus gender, including B. subtilis, B. amyloliquefaciens, and B. pumilus. Among these antagonistic strains, No. 18 showed the strongest inhibitory activity against the two pathogens (Foc4 and Cg) (Figure 3 and Table 5), No. 50 exhibited the same strongest inhibitory activity against $\mathrm{Cg}$ as No. 18, while No. 33 showed weak inhibitory activity against Foc4 (Figure 3 and Table 5).

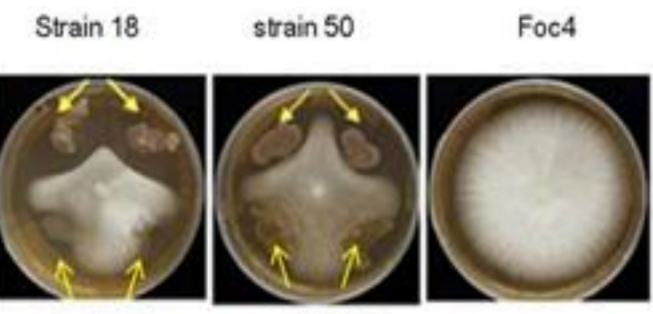

Strain 23

strain 33

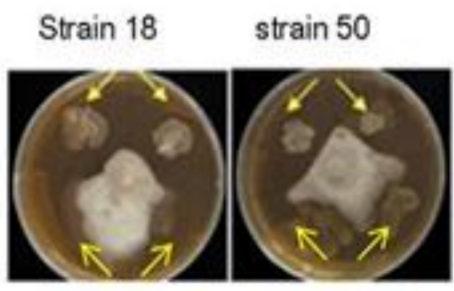

Strain 23
$\mathrm{Cg}$

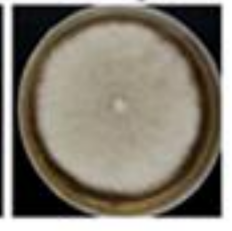

strain 33

Figure 3. Macroscopic observation of the inhibitory activity corresponding to strain No. 18 and No. 50 against the two pathogens tested (Fusarium oxysporum f. sp. cubense race 4 (Foc4) and Colletotrichum gloeosporioides $(\mathrm{Cg})$. 
Table 5. Inhibitory activity of the strains in the screening of antagonistic bacteria.

\begin{tabular}{cccc}
\hline Strains Code & \multicolumn{2}{c}{ Inhibitory Activity } & Name of Strains \\
\hline & Foc4 & Cg & \\
5 & + & + & Vibrio neocaledonicus \\
12 & + & + & Bacillus amyloliquefaciens strain PD9 \\
16 & ++ & ++ & Bacillus subtilis \\
18 & + & + & Bacillus aerophilus \\
19 & +++ & +++ & Bacillus amyloliquefaciens \\
20 & ++ & - & Bacillus pumilus \\
21 & ++ & ++ & Bacillus velezensis strain Lzh-a42 \\
33 & ++ & -+ & Bacillus sp. \\
47 & + & - & Bacillus aerophilus \\
50 & ++ & +++ & Bacillus sp. strain M4 \\
52 & + & - & Bacillus subtilis \\
& ++ & Bacillus aerophilus
\end{tabular}

Coding crosses relates to the qualitative results of the trial corresponding in this scale + : weak,$++:$ moderate,+++ : good and ++++ : excellent. ${ }^{*}$ Not confidently identified.

\section{Discussion}

Marine organisms are recognized as a source of compounds with biological activity equal to or greater than terrestrial organisms, and from them, compounds with anti-inflammatory, anti-cancer, antiviral activity [21,40], and antifouling activity [41] have been isolated.

In the present study, 55 ethyl acetate extracts from 55 bacterial strains belonging to 9 bacterial families (Vibrionaceae, Bacillaceae, Microbacteriaceae, Aerococcaceae, Brevibacteriaceae, Staphylococcaceae, Pseudoalteromonadaceae, Enterobacteriaceae, and Shewanellaceae) were evaluated for their AChE and AG inhibitory activity. The percentage of inhibition of the four concentrations employed of the active strains is shown in Table 2. According to Table 2, considering the families that showed AChEI activity, the majority of the strains evaluated in the present study belong to Vibrionaceae (45.4\%) and Bacillaceae (29.1\%) with comparable data of the positive control (Huperzine A-HupA). HupA is an alkaloid isolated from the Chinese herb Huperzia serrata. We chose HupA because it is a powerful, highly specific, and reversible inhibitor of acetylcholinesterase (AChE). From the 55 ethyl acetate extracts evaluated, 23 of them (41.07\%) showed strong to moderate AChE inhibitory activity. The strongest AChE inhibitory activities were exhibited by the strains coded with 1, 3, and 38 corresponding to $V$. neocaledonicus with $98.9 \%, 93.0 \%$, and $90.8 \%$, respectively, at $50 \mu \mathrm{g} / \mathrm{mL}$. In addition, two strains (V. neocaledonicus and S. kloosii) rendered positive results in both bioassays of inhibition, acetylcholinesterase, and alphaglucosidase.

It has been reported that Vibrio bacteria produce compounds with different and interesting biological activities [42-44]. In our results, the activity of AChEI has been detected in a good number of bacteria associated with coral reef and belonging to the Vibrionaceae family, which makes it an important objective for the isolation and characterization of bioactive compounds responsible for this biological activity and inhibition of other enzymes such as alphaglucosidase and xanthine oxidase. Therefore, this confirms that marine organisms have a great potential for the discovery of new and valuable compounds with different degrees of pharmaceutical applications.

Another common problem affecting human health is related to elevated concentrations of uric acid in the bloodstream leading to the formation of gout, characterized by hyperuricemia and recurrent attacks of arthritis. XOIs may help as therapeutic agents for hyperuricemia and/or gout. Certain active constituents like flavonoids and others polyphenolic compounds have been reported to possess XOI [33]. Considering Table 3, we evaluated 12 extracts of bacteria strains on the enzyme XO and found that some of them may inhibit the enzyme. From Table 3, strains with code 25, 38, and 14, all corresponding to $V$. neocaledonicus, showed moderate $\mathrm{XO}$ inhibitory activity with percentages of inhibition for the highest concentration in each case $(125 \mu \mathrm{g} / \mathrm{mL})$ of $31.17,27.89$, and $26.60 \%$, 
respectively. Although the percentage was not high, these findings open the possibility of isolation of new natural compounds, which can be potent inhibitors of $\mathrm{XO}$ and lead to the growing interest in the investigation of marine organisms. In the same way, from the screening by TLC on Table 4, the strain V. neocaledonicus (code 38) has polyphenolic compounds and, in general, the strains of $V$. neocaledonicus (codes 1,3,5, and 38) contain polyphenols that could explain their moderate activity on the XO enzyme.

Consequently, the observation and monitoring by TLC revealed that from the chemical side, $V$. neocaledonicus has a great richness in relation to the other strains cultivated and evaluated (Table 4). These qualitative differences between the extracts can explain, in a general way, the results obtained in the bioassays, since vibrio shows a great chemical richness in comparison with the other extracts. Likewise, the metabolic production is affected by the composition of the medium and the growth conditions. All these factors influence the activity presented by each strain according to its chemical composition. Considering this information, both criteria were taken into consideration (the chemical and the biological to choose this strain and to propose future studies related to its chemical composition).

Finally, in order to contribute to the knowledge of the bacteria chosen for the activities described above, an assay and subsequent macroscopic observation were made with all the strains to evaluate its inhibitory activity on two pathogens fungi that seriously affect large and important crops such as banana and mango in tropical and subtropical areas.

One of the fungi tested was F. oxysporum f. sp. cubense race 4 (Foc4), which is classified with the highest degree of pathogenicity, causing the wilt of banana, affecting the vascular system of the plant [45-47]. This condition spreads rapidly, and methods for effective control have not been developed yet [48-50]. In agreement with our macroscopic observation of the inhibitory activity against Foc4, from Figure 3, strain No. 18 corresponding to B. amyloliquefaciens showed a high inhibitory activity against Foc4. Perhaps, these results can be explained based on a probable interaction between the metabolites that produce the bacteria and inhibit the growth of the pathogenic fungus.

Another important pathogenic fungus is the C. gloeosporioides. In tropical zones and under favorable conditions, it causes the anthracnose disease, affecting the foliage, the stems, and the fruits, and causing losses before and after the harvest in mango, papaya, guava, cherimoya, pomegranate, and other fruit crops [51].

Considering Figure 3 , the macroscopic observation of the inhibitory activity against $C$. gloeosporioides (Cg) showed that the strains with code No. 18 and 50, corresponding to B. amyloliquefaciens and B. subtilis, respectively, have the strongest inhibitory activity against $\mathrm{Cg}$. In addition, based on Table 4, the qualitative analysis by TLC indicates that both bacteria contain terpene type compounds and polyphenols that could be interacting with the fungus and thus inhibit its growth. Moreover, one of the main alternatives in the control of phytopathogenic fungi is the use of microorganisms such as the species of Aspergillus and Trichoderma, which have inhibited the growth of phytopathogenic [52,53].

The antagonistic properties by which the strains of Trichoderma act as biological control agents are based on the activation of multiple mechanisms, such as competition per nutrients and space, the modification of the environmental conditions, the stimulation of the growth, and the activation of defensive mechanisms of the plants by antibiosis and mycoparasitism. These mechanisms involve the production of components and metabolites as growth factors, hydrolytic enzymes, and antibiotics [54].

\section{Conclusions}

In summary, our results contribute to the knowledge on the use of marine products by finding that they are important sources of compounds of AChEI enzyme on an in vitro model. In this research report, we outlined an interesting finding that reveals the inhibition of the activity of the acetylcholinesterase and alpha glucosidase enzymes by two isolated coral reef bacteria from the South China Sea. This is the first report of the inhibitory activity of acetylcholinesterase and alphaglucosidase 
for the strain $V$. neocaledonicus, and, also, it is the first report of inhibitory activity of both enzymes mentioned by bacteria from Vibrionaceae and Staphylococcaceae families in this area of the world.

Future studies will be conducted through the analysis of their chemical composition in order to understand, relate, and try to explain their biological activity with the metabolites that this strain produces. These results suggested the potential feasibility of $V$. neocaledonicus, as well as their possible applications in the pharmaceutical industry. It is important to focus efforts on the discovery of AChEIs, AGIs, and XOIs from natural sources. Several potential inhibitors in marine bacteria are waiting to be discovered to provide natural sources for the mass production of these therapeutic compounds.

Supplementary Materials: The following are available online at http:/ / www.mdpi.com/2077-1312/6/2/33/s1. Figure S1: Qualitative chemical analysis.

Acknowledgments: This work was supported by Hainan Provincial Key Research and Development Program (ZDYF 2016163).

Author Contributions: Tan Lin formulated the experiments; Gómez-Betancur Isabel and Guo Suxia performed the experiments; Tan Lin and Gómez-Betancur Isabel analyzed the data; Tan Lin, Chen Chang, and Ma Funing contributed with reagents/materials/analysis tools; Gómez-Betancur Isabel wrote the paper.

Conflicts of Interest: The authors declare no conflict of interest.

\section{References}

1. Wiesner, J.; Kriz, Z.; Kuca, K.; Jun, D.; Koca, J. Acetylcholinesterases-The structural similarities and differences. J. Enzym. Inhib. Med. Chem. 2007, 22, 417-424. [CrossRef] [PubMed]

2. Khan, M.T. Molecular interactions of cholinesterases inhibitors using in silico methods: Current status and future prospects. New Biotechnol. 2009, 25, 331-346. [CrossRef] [PubMed]

3. Heinrich, M.; Lee, T. Galanthamine from snowdrop-The development of a modern drug against Alzheimer's disease from local Caucasian knowledge. J. Ethnopharmacol. 2004, 92, 147-162. [CrossRef] [PubMed]

4. Wang, R.; Yan, H.; Tang, X.C. Progress in studies of huperzine A, a natural cholinesterase inhibitor from Chinese herbal medicine. Acta Pharmacol. Sin. 2006, 27, 1-26. [CrossRef] [PubMed]

5. Bonnard, I.; Jhaumeer-Laulloo, S.B.; Bontemps, N.; Banaigs, B.; Aknin, M. New Lobane and Cembrane Diterpenes from Two Comorian Soft Corals. Mar. Drugs 2010, 8, 359-372. [CrossRef] [PubMed]

6. Langjae, R.; Bussarawit, S.; Yuenyongsawad, S.; Ingkaninan, K.; Plubrukarn, A. Acetylcholinesterase inhibiting steroidal alkaloid from the sponge Corticium sp. Steroids 2007, 72, 682-685. [CrossRef] [PubMed]

7. Yoon, N.Y.; Chung, H.Y.; Kim, H.R.; Choi, J.S. Acetyl and butyryl cholinesterase inhibitory activities of sterols and phlorotannins from Ecklonia stolonifera. Fish. Sci. 2008, 74, 200-207. [CrossRef]

8. Nukoolkarn, V.S.; Saen-oon, S.; Rungrotmongkol, T.; Hannongbua, S.; Ingkaninan, K.; Suwanborirux, K. Petrosamine, a potent anticholinesterase pyridoacridine alkaloid from a Thai marine sponge Petrosia n. sp. Bioorg. Med. Chem. 2008, 16, 6560-6567. [CrossRef] [PubMed]

9. Kalauni, S.K.; Choudhary, M.I.; Khalid, A.; Manandhar, M.D.; Shaheen, F.; Gewali, M.B. New cholinesterase inhibiting steroidal alkaloids from the leaves of Sarcococca coriacea of Nepalese origin. Chem. Pharm. Bull. 2002, 50, 1423-1426. [CrossRef] [PubMed]

10. Rahman, A.; Wahab, A.T.; Nawas, S.A.; Choudhary, M.I. New cholinesterase inhibiting bisbenzylisoquinoline alkaloids from Cocculus pendulus. Chem. Pharm. Bull. 2004, 52, 802-806. [CrossRef]

11. Ahmad, W.; Ahmad, B.; Ahmad, M.; Iqbal, Z.; Nisar, M.; Ahmad, M. In vitro inhibition of acetylcholinesterase, butyrylcholinesterase and lipoxygenase by crude extract of Myricaria elegans Royle. J. Biol. Sci. 2003, 11, 1046-1049.

12. Sung, S.Y.; Kang, S.Y.; Lee, K.Y.; Park, M.J.; Kim, J.H.; Park, J.H.; Kim, Y.C.; Kim, J.; Kim, Y.C. (+)- $\alpha$-Viniferin, a stilbene trimer from Caranga chamlague inhibits acetylcholinesterase. Biol. Pharm. Bull. 2002, 25, 125-127. [CrossRef] [PubMed]

13. American Diabetes Association (ADA). Diagnosis and classification of diabetes mellitus. Diabetes Care 2009, 101, 274.

14. Fauci, A.S.; Braunwald, E.; Kasper, D.L. Diabetes Mellitus. In Principles of Internal Medicine; Mc-Graw Hill: New York, NY, USA, 2009. 
15. Abesundara, K.J.; Matsui, T.; Matsumoto, K. Alfa-glucosidase inhibitory activity of some Sri Lanka plant extracts, one of which, Cassia auriculata, exerts a strong antihyperglycemic effect in rats comparable to therapeutic drug acarbose. J. Agric. Food Chem. 2004, 52, 2541. [CrossRef] [PubMed]

16. Önal, S.; Timmur, S.; Okuttucu, B.; Zihnioglu, A. Inhibition of $\alpha$-glucosidase by aqueous extracts of some potent antidiabetic medicinal herbs. Prep. Biochem. Biotechnol. 2005, 35, 29. [CrossRef] [PubMed]

17. Li, Y.; Wen, S.; Kota, B.P.; Peng, G.; Li, G.Q.; Yamahara, J.; Roufogalis, B.D. Punica granatum flower extract, a potent $\alpha$-glucosidase inhibitor, improves postprandial hyperglycemia in Zucker diabetic fatty rats. J. Ethnopharmacol. 2005, 99, 239. [CrossRef] [PubMed]

18. Jung, M.; Park, M.; Chul, H.L.; Kang, Y.; Seok-Kang, E.; Ki-Ki, S. Antidiabetic agents from medicinal plants. Curr. Med. Chem. 2006, 13, 1. [CrossRef]

19. Copeland, R.A. Why Enzymes as Drug Targets? Evaluation of Enzyme Inhibitors in Drug Discovery; John Wiley \& Sons, Inc.: Hoboken, NJ, USA, 2013; pp. 1-23.

20. Choma, I.M.; Grzelak, E.M. Bioautography detection in thin layer chromatography. J. Chromatogr. A 2011, 1218, 2684-2691. [CrossRef] [PubMed]

21. Montaser, R.; Luesch, H. Marine natural products: A new wave of drugs? Future. Med. Chem. 2011, 3, 1475-1489. [CrossRef] [PubMed]

22. Reid, P.C.; Gorick, G.; Edwards, M. Climate Change and Marine Ecosystem Research; Sir Alister Hardy Foundation for Ocean Science (SAHFOS): Citadel Hill, UK, 2011.

23. Huehn, S.; Eichhorn, C.; Urmersbach, S.; Breidenbach, J.; Bechlars, S.; Bier, N.; Alter, T.; Bartelt, E.; Frank, C.; Appel, B.; et al. Pathogenic vibrios in environmental, seafood and clinical sources in Germany. Int. J. Med. Microbiol. 2014, 304, 843-850. [CrossRef] [PubMed]

24. Le Roux, F.; Wegner, K.M.; Baker-Austin, C.; Vezzulli, L.; Osorio, C.R.; Amaro, C. The emergence of Vibrio pathogens in Europe: Ecology, evolution, and pathogenesis, Paris, 11-12th March 2015. Front. Microbiol. 2015, 6, 830. [PubMed]

25. Vaishampayan, P.; Probst, A.; Krishnamurthi, S.; Ghosh, S.; Osman, S.; McDowall, A.; Ruckmani, A.; Mayilraj, S.; Venkateswaran, K. Bacillus horneckiae sp. nov., isolated from a spacecraft-assembly clean room. Int. J. Syst. Evol. Microbiol. 2010, 60, 1031-1037. [CrossRef] [PubMed]

26. Seiler, H.; Wenning, M.; Scherer, S. Domibacillus robiginosus gen. nov., sp. nov., isolated from a pharmaceutical clean room. Int. J. Syst. Evol. Microbiol. 2013, 63, 2054-2061. [CrossRef] [PubMed]

27. Bottone, E.J. Bacillus cereus, a volatile human pathogen. Clin. Microbiol. Rev. 2010, 23, 382-398. [CrossRef] [PubMed]

28. Marquez, M.C.; Sanchez-Porro, C.; Ventosa, A. Hallophilic and Haloakalophilic, Aerobic Endospore-Forming Bacteria in Soil; Springer: New York, NY, USA, 2011; pp. 309-339.

29. Schmidt, T.R.; Scott, E.J.; Dyer, D.W. Whole-genome phylogenies of the family Bacillaceae and expansion of the sigma factor gene family in the Bacillus cereus species-group. BMC Genom. 2011, 12, 430. [CrossRef] [PubMed]

30. Hoyles, L.; Honda, H.; Logan, N.; Halket, G.; La Ragione, R.; McCartney, A. Recognition of greater diversity of Bacillus species and related bacteria in human faeces. Res. Microbiol. 2012, 163, 3-13. [CrossRef] [PubMed]

31. Ellman, G.L.; Courtney, D.; Andres, V.; Featherston, R.M. A new and rapid colorimetric determination of acetylcholinesterase activity. Biochem. Pharmacol. 1961, 7, 88-95. [CrossRef]

32. Miroslav, P.; Martina, H.; Kamil, K.; Jean-Pierre, S. Assessment of Acetylcholinesterase Activity Using Indoxylacetate and Comparison with the Standard Ellman's Method. Int. J. Mol. Sci. 2011, 12, 2631-2640.

33. Danijela, K.; Danica, D.; Gordana, S.; Ivan, P.; Aleksandra, Y.; Jovana, I. Xanthine Oxidase: Isolation, Assays of Activity, and Inhibition. J. Chem. 2015. [CrossRef]

34. Pistia-Brueggeman, G.; Hollingsworth, R.I. A preparation and screening strategy for glycosidase inhibitors. Tetrahedron 2001, 57, 8773. [CrossRef]

35. Valentao, P.; Frenandes, E.; Carvalho, F.; Andrade, B.P.; Seabra, R.M.; Bastos, M.L. Studies on the antioxidant activity of Lippia citfiodora infusion: Scavenging effect on superoxide radical, hydroxyl radical and hypochlorous acid. Biol. Pharm. Bull. 2002, 25, 1324-1327. [CrossRef] [PubMed]

36. López-Cruz, R.I.; Zenteno-Savín, T.; Galván-Magaña, F. Superoxide production, oxidative damage and enzymatic antioxidant defenses in shark skeletal muscle. Comp. Biochem. Physiol. 2010, 156, 50-56. [CrossRef] [PubMed] 
37. Harborne, J.B. A Guide to Modern Techniques of Plant Analysis, Chapman and Hall, London. Phytochem. Methods 1980, 278, 1980.

38. Feng, S.; Wang, R.; Lin, K.; Zhang, Y.; Du, L.; Fan, X.; Cao, W. Identification of Strain Bs-208 and Its Inhibition Against Plant Pathogenic Fungi. Chin. J. Biol. Control 2003, 19, 171-174.

39. Bladt, S. Plant Drug Analysis: A Thin Layer Chromatography Atlas; Springer: Berlin/Heidelberg, Germany, 1996.

40. Newman, D.J.; Cragg, G.M. Natural Products as Sources of New Drugs over the 30 Years from 1981 to 2010. J. Nat. Prod. 2012, 75, 311-335. [CrossRef] [PubMed]

41. Fusetani, N. Antifouling marine natural products. Nat. Prod. Rep. 2011, 28, 400-410. [CrossRef] [PubMed]

42. Hill, R.T.; Hamann, M.T.; Enticknap, J.J.; Rao, K.V. Kahalalide-Producing Bacteria; PCT/US2004/036201 May 2005. Available online: http:/ / www.wipo.int/patentscope/search/en/WO2005042720 (accessed on 16 August 2011).

43. Mansson, M.; Nielsen, A.; Kjærulff, L.; Gotfredsen, C.H.; Wietz, M.; Ingmer, H.; Gram, L.; Larsen, T.O. Inhibition of virulence gene expression in Staphylococcus aureus by novel depsipeptides from a Marine photobacterium. Mar. Drugs 2011, 9, 2537-2552. [CrossRef] [PubMed]

44. Hamann, M.T. Technology Evaluation: Kahalalide F, PharmaMar. Curr. Opin. Mol. Ther. 2004, 6, 657-665. [PubMed]

45. Fernandez, D.; Assigbese, K.; Dubois, M.P.; Geiger, J.P. Molecular characterization of races and vegetative compatibility groups in Fusarium oxysporum f. sp. Vasinfectum. Appl. Environ. Microbiol. 1994, 60, 4039-4046. [PubMed]

46. Nel, B. Isolation and characterization of nonpathogenic Fusarium oxysporum isolates from the rhizosphere of healthy banana plants. Plant Pathol 2006, 55, 207-216. [CrossRef]

47. Van Den Berg, N.; Berger, D.K.; Hein, I.; Birch, P.R.J.; Wingfield, M.J.; Viljoen, A. Tolerance in banana to Fusarium wilt is associated with early up-regulation of cell wall-strengthening genes in the roots. Mol. Plant Pathol. 2007, 8, 333-341. [CrossRef] [PubMed]

48. Sivamani, E. Biological control of Fusarium oxysporum f. sp. cubense in banana by inoculation with Pseudomonas fluorescens. Plant Soil 1988, 107, 3-9.

49. Peng, H.X.; Sivasithamparam, K.; Turner, D.W. Chlamydospore germination and Fusarium wilt of banana plantlets in suppressive and conducive soils are affected by physical and chemical factors. Soil Biol. Biochem. 1999, 31, 1363-1374. [CrossRef]

50. Thangavelu, R.; Palaniswami, A.; Velazhahan, R. Mass production of Trichoderma harzianum for managing Fusarium wilt of banana. Agric. Ecosyst. Environ. 2004, 103, 259-263. [CrossRef]

51. Meenakshi, S.; Saurabh, K. Colletotrichum gloeosporioides: An Anthracnose Causing Pathogen of Fruits and Vegetables. Biosci. Biotechnol. Res. Asia 2015, 12, 1233-1246.

52. Quiroz-Sarmiento, V.R.; Ferrera-Cerrato, R.; Alarcón, A.; Lara-Hernández, M.E. Antagonismo in vitro de cepas de Aspergillus y Trichoderma hacia hongos filamentosos que afectan el cultivo de ajo. Rev. Mex. Micol. 2008, 26, 27-34.

53. Hasan, M.M.; Rahman, S.M.E.; Kim, G.H.; Abdallah, E.; Oh, D.H. Antagonistic Potentiality of Trichoderma harzianum Towards Seed-Borne Fungal Pathogens of Winter Wheat cv. Protiva In Vitro and In Vivo. J. Microbiol. Biotechnol. 2012, 22, 585-591. [CrossRef] [PubMed]

54. Benítez, T.; Rincón, A.M.; Limón, M.C.; Codón, A.C. Biocontrol Mechanisms of Trichoderma strains. Int. Microbiol. 2004, 7, 249-260. [PubMed]

(C) 2018 by the authors. Licensee MDPI, Basel, Switzerland. This article is an open access article distributed under the terms and conditions of the Creative Commons Attribution (CC BY) license (http:/ / creativecommons.org/licenses/by/4.0/). 